\title{
Impact of WOWW's Fine Arts Enriched Education Programming
}

\author{
Laurie A. Sharp
}

Asst. Prof., West Texas A\&M University, USA, lsharp@wtamu.edu

\section{Ali Tiegs}

Window On a Wider World, ali.tiegs@windowonawiderworld.org

Learning through the fine arts possesses many benefits, yet efforts to address the arts within public schools, particularly rural schools, are insufficient. In an effort to support rural public schools in Texas, Window On a Wider World (WOWW) began providing fine arts enriched education programming in 2006 to area partner schools that serve students at the elementary grade levels. The purpose of the current study was to explore the impact of WOWW's fine arts enriched education programming on student academic achievement with state-mandated standardized assessments, as well as campus attendance rates. This study employed an ex-post facto, causal-comparative quantitative research design to analyze mean differences between WOWW partner schools and non-WOWW partner schools. Data were collected from the 2012-2013, 2013-2014, 2014-2015, and 2015-2016 school years and analyzed using independent samples $t$-tests. Two levels of data analyses were employed, which produced four statistically significant findings among all public schools and five among rural public schools. Implications of these findings were shared, as well as limitations and recommendations for future studies.

Keywords: learning through the arts, public schools, rural schools, elementary students, education programming

\section{INTRODUCTION}

Learning through the fine arts has numerous benefits for students at any age. Learning through the fine arts in all forms (i.e., dance, music, theater, and visual arts) encourages students to be creative, imaginative, and innovative thinkers (Arts Education Partnership, 2016). Moreover, students develop instrumental 21st century skills, such as critical thinking, problem solving, communication, and collaboration, as they engage in learning activities enriched with the fine arts. Several research studies have shown that learning through the fine arts enhances academic performance and engagement in school, social, and community activities among all students (e.g., Ingram \& Riedel, 2003; Luftig, 2000; Snyder \& Cooper, 2015). However, the marginalization of fine arts

Citation: Sharp, L. A., \& Tiegs, A. (2018). Impact of WOWW's Fine Arts Enriched Education Programming. International Journal of Instruction, 11(2), 25-40. https://doi.org/10.12973/iji.2018.1123a 
instruction within public schools precludes many students from experiencing the rich benefits that accompany learning through the fine arts.

\section{REVIEW OF LITERATURE}

During the 2009-2010 academic year, the National Center for Education Statistics conducted a study among public schools located throughout the United States to obtain information related to efforts with learning through the arts (Parsad \& Spiegelman, 2012). Compared to the preceding studies conducted during the 1994-1995 and 19992000 academic years, this study was a much more comprehensive analysis and explored: (a) accessibility of fine arts instruction, (b) frequency of fine arts instruction, (c) availability and teaching load of fine arts specialists, and (d) ways in which the fine arts were integrated into classroom instruction. Findings revealed three primary approaches schools used to address learning through the arts: (1) school-wide program offerings, (2) integrated classroom instruction, and (3) fine arts education partnerships. However, findings also revealed great inequities and inconsistencies with learning through the arts, especially among schools that serve large populations of students who are at-risk, economically disadvantaged, or live in rural communities.

These inequities and inconsistencies with fine arts instruction are discouraging, particularly since much literature has described the influence of learning through the arts on cognitive processes (Bolwerk, Mack-Andrick, Lang, Dörfler, \& Maihöfner, 2014; Demarin, Bedeković, Puretić, \& Pašić, 2016; Dunbar, 2008; Posner, Rothbart, Sheese, \& Kieras, 2008; Solso, 1994). Specifically among students at the elementary grade levels, much literature has also described parallels between the integration of:

- $\quad$ mathematics and (a) dance (Helsa \& Hartono, 2011; Rosenfeld, 2011); (b) music (An, Capraro, \& Tillman, 2013; Jones \& Pearson, 2013); (c) theater (Fleming, Merrell, \& Tymms, 2004; Sutil, 2014); and (d) visual arts (Brezovnik, 2015; Bush, Karp, Lentz, \& Nadler, 2017);

- $\quad$ reading and (a) dance (Block, 2001; Greenfader \& Brouillette, 2013); (b) music (Hall \& Robinson, 2012; Hansen \& Bernstorf, 2002); (c) theater (Greenfader \& Brouillette, 2013; Young, Valadez, \& Gandara, 2016); and (d) visual arts (LaBrocca \& Morrow, 2016; Van Buren, 1986);

- $\quad$ science and (a) dance (McPherson, 2009; Shaw \& Nygard, 1997); (b) music (Carrier, Wiebe, Gray, \& Teachout, 2011; Crowther, Mcfadden, Fleming, \& Davis, 2016); (c) theater (Kerby, Cantor, Weiland, Babiarz, \& Kerby, 2010; Plankis, Ramsey, Ociepka, \& Martin, 2016); and (d) visual arts (Dambekalns \& Medina-Jerez, 2012; Porter, Yokoi, \& Yee, 2011); and

- $\quad$ writing and (a) dance (Adams, 2016; Frambaugh-Kritzer, Buelow, \& Steele, 2015); (b) music (Christianakis, 2011; Frasher, 2014); (c) theater (Frambaugh-Kritzer et al., 2015; Lee \& Enciso, 2017); and (d) visual arts (Leigh, 2012; Poldbereg, Trainin, \& Andrzejczak, 2013).

A number of research studies have disseminated findings that showed learning through the fine arts improves academic performance (Anderson, 2012; Anderson \& Loughlin, 
2014; Ingram \& Riedel, 2003; Peppler, Powell, Thompson, \& Catterall, 2014), as well as retention of academic content (Hardiman, Rinne, \& Yarmolinskaya, 2014; Rinne, Gregory, Yarmolinskaya, \& Hardiman, 2011). However, literature that explored learning through the fine arts specifically among rural public schools was much more limited and consisted mostly of practitioner pieces that described specific instructional methods (Campbell, 2001; Clark \& Zimmerman, 2000; Raymond \& Broderick, 2007). At the time of the current study, detailed studies that reported original research on this topic was even more narrow (Garcia, Jones, \& Isaacson, 2015; LaGarry \& Richard, 2016).

\section{CONTEXT}

In 1967, the Texas Legislature created regional education service centers (ESCs) to support public school districts in Texas with enhancing education among students at a local level (Texas System of ESCs, n.d.). ESCs provide public schools located in their region with professional development, resources, and other education services. Currently, 20 ESCs serve over 1,200 public school districts in Texas.

Public school districts in Texas are also categorized by type: (a) major urban, (b) major suburban, (c) other central city, (d) other central city suburban, (e) independent town, (f) non-metropolitan: fast growing, (g) non-metropolitan: stable, (h) rural, and (i) charter school districts (Texas Education Agency [TEA], 2017b). According to the most recent data available, the largest public school district type in Texas was rural and consisted of 453 public school districts (TEA, 2017c).

ESC Region 16 currently provides support to 62 public school districts located in the Texas Panhandle (ESC Region 16, n.d.), of which 41 public schools have been categorized as rural (TEA, 2017b). In 2004, an analysis was conducted throughout ESC Region 16 to determine the state of fine arts instruction among its public school districts (Wiles, 2004). Findings from this analysis revealed that more than half of the region's public schools lacked adequate fine arts programming. Although the fine arts are not part of the state's accountability system, Texas has adopted mandatory curriculum standards for dance, music, theater, and visual arts (TEA, 2017a). However, it has become apparent that rural public schools require additional support with providing students access to quality experiences for learning through the arts.

Dedicated to enriching the education of students at the elementary grade levels, Window On a Wider World (WOWW) began providing fine arts enriched education programming in 2006 to their partner schools in Texas's ESC Region 16 area. Now in its eleventh year, WOWW facilitates over 160 fine arts enriched education programs with strong curriculum ties to mandatory curriculum standards through established partnerships with 29 area arts, science, and cultural non-profit partner organizations. These partner organizations have designed their programs to be offered as field trips at locations away from a school campus or outreach experiences that may take place directly at a school campus. In order to meet the needs of the public schools, many of WOWW's partner organizations offer their programming in both formats. 
By facilitating both field trips and outreach experiences, WOWW provides public schools, particularly those located in rural communities, with access to enriched arts, science, and cultural education programming. The number of public schools that WOWW serves each year has grown since its inception and included 44 school campuses located in 34 school districts at the time of the current study. With the benefits of learning through the arts being so clearly documented in available literature (Arts Education Partnership, 2016; Ingram \& Riedel, 2003; Luftig, 2000; Snyder \& Cooper, 2015), the purpose of the current study was to explore the impact of participation in WOWW's fine arts and enriched education programming among public schools located in Texas's ESC Region 16 area.

\section{METHOD}

\section{Sampling}

To achieve the purpose for the current study, an ex-post facto, causal-comparative quantitative research design was utilized. Two groups were established with which to analyze data:

- Group 1: WOWW partner schools: This group included all WOWW partner schools. $(n=54)$

- Group 2: non-WOWW partner schools: This group included all public schools located in the ESC Region 16 area that served students in the elementary grade levels. $(n=135)$

\section{Data collection}

Data for all public schools included in analyses were collected via the Texas Academic Performance Reports (TAPR) portal (TEA, 2017d). School campus-level data were collected from available TAPR reports for each public school during the following school years: 2012-2013, 2013-2014, 2014-2015, and 2015-2016. Data collected included campus attendance rates and State of Texas Assessments of Academic Readiness (STAAR) Level II performance standards for required assessments administered in Grade 3 (i.e., Mathematics \& Reading), Grade 4 (Mathematics, Reading, \& Writing), and Grade 5 (i.e., Mathematics, Reading, and Science). TAPR data for 2014-2015 STAAR Mathematics were unavailable since revised curriculum standards were implemented, and TAPR data for 2015-2016 attendance rates were unavailable since reported data lags one year behind.

Data for WOWW partner schools were collected through a written request submitted to WOWW's executive director. Data collected included the names of participating WOWW partner schools during the selected school years under analysis. Table 1 reflects collected data for WOWW partner schools, as well as the number of school districts that were categorized as rural. 
Table 1

WOWW Partner Schools

\begin{tabular}{llc}
\hline School Year & WOWW Partner Schools & Rural School Districts \\
\hline $2012-2013$ & 32 & 9 \\
$2013-2014$ & 36 & 10 \\
$2014-2015$ & 41 & 19 \\
$2015-2016$ & 44 & 19 \\
\hline
\end{tabular}

\section{Data analyses}

Data collected were entered into IBM SPSS Statistics 22. Data were analyzed using independent samples $t$-tests to determine mean differences between Group 1 and Group 2 for Level II STAAR academic performance and attendance rates. The following null hypotheses guided data analyses:

$\mathrm{H}_{0} 1$ : There is no statistically significant difference in STAAR academic performance between Group 1 and Group 2.

$\mathrm{H}_{0}$ 2: There is no statistically significant difference in attendance rates between Group 1 and Group 2.

Two levels of analyses were used to explore each null hypothesis. The first level of analysis explored mean differences between Group 1 and Group 2 among all students. During this level of analysis, all available TAPR data collected for all school campuses were included. The second level of analysis explored mean differences between Group 1 and Group 2 among students in public school districts that were categorized as rural. During this level of analysis, only available TAPR data collected for public school campuses located in school districts that were categorized as rural were included.

Prior to conducting statistical analyses, each data set was inspected to confirm that each assumption was satisfied (Lund Research Ltd., 2013). After this confirmation, statistical significance was pre-established at $a<.05, \beta=.20$ (Cohen, 1992). Effect sizes for findings that showed statistical significance were reported as small (.20), medium (.50), or large (.80).

\section{FINDINGS}

\section{Level 1 analysis: Students in all public schools}

This level of data analysis explored the impact of participation in WOWW's fine arts enriched education programming on the academic achievement and attendance rate among students in all public schools. Findings from this level of analysis are reported by school year.

2012-2013 school year

As shown in Table 2, a cursory comparison of mean scores reflected several differences, and independent samples $t$-tests were performed to explore the data further and determine statistical significance. Findings revealed one statistically significant finding 
with attendance rates, which rejected the null hypothesis $[t(43)=2.11, p=.04]$. Cohen's $d$ was calculated at .38, which was considered a small effect.

Table 2

All public schools in Texas's ESC Region 16 Area

\begin{tabular}{|c|c|c|c|c|c|c|c|c|c|c|}
\hline & \multicolumn{3}{|c|}{ WOWW } & \multicolumn{3}{|c|}{ Non-WOWW } & \multirow[b]{2}{*}{$t$} & \multirow[b]{2}{*}{$p$} & \multicolumn{2}{|c|}{$95 \% \mathrm{CI}$} \\
\hline & $n$ & $M$ & $S D$ & $n$ & $M$ & $S D$ & & & $\mathrm{LL}^{-}$ & UL \\
\hline \multicolumn{11}{|l|}{$2012-2013$} \\
\hline 3 Math & 23 & 66.0 & 17.3 & 79 & 73.4 & 17.3 & -1.81 & .07 & -15.56 & 0.73 \\
\hline 3 Reading & 27 & 79.5 & 16.1 & 84 & 81.7 & 13.3 & -0.70 & .49 & -8.32 & 3.98 \\
\hline 4 Math & 27 & 71.1 & 17.5 & 79 & 72.6 & 16.4 & -0.40 & .69 & -8.86 & 5.89 \\
\hline 4 Reading & 27 & 77.2 & 14.2 & 86 & 73.1 & 14.9 & 1.23 & .22 & -2.43 & 10.46 \\
\hline 4 Writing & 27 & 70.3 & 16.3 & 83 & 71.3 & 15.9 & -0.28 & .78 & -8.02 & 6.04 \\
\hline 5 Math & 26 & 75.7 & 13.7 & 77 & 75.4 & 16.8 & .08 & .93 & -6.92 & 7.53 \\
\hline 5 Reading & 26 & 81.5 & 11.8 & 77 & 77.3 & 14.3 & 1.33 & .18 & -2.05 & 10.29 \\
\hline 5 Science & 26 & 72.2 & 16.8 & 73 & 74.5 & 13.7 & -0.69 & .49 & -8.90 & 4.29 \\
\hline Attendance & 32 & 96.5 & 0.8 & 102 & 96.3 & 0.5 & 2.11 & .04 & 0.02 & 0.49 \\
\hline \multicolumn{11}{|l|}{$2013-2014$} \\
\hline 3 Math & 30 & 71.1 & 16.6 & 80 & 75.3 & 15.9 & -1.23 & .22 & -11.06 & 2.59 \\
\hline 3 Reading & 31 & 77.7 & 13.9 & 83 & 80.5 & 12.2 & -1.04 & .30 & -8.04 & 2.52 \\
\hline 4 Math & 29 & 71.3 & 13.4 & 81 & 75.6 & 17.3 & -1.21 & .23 & -11.29 & 2.75 \\
\hline 4 Reading & 28 & 73.7 & 14.5 & 82 & 76.9 & 14.1 & -1.01 & .31 & -9.32 & 3.01 \\
\hline 4 Writing & 28 & 75.9 & 14.5 & 80 & 69.5 & 15.3 & -2.00 & .05 & -12.82 & -0.05 \\
\hline 5 Math & 29 & 91.9 & 7.1 & 73 & 90.0 & 10.9 & 0.86 & .39 & -2.47 & 6.24 \\
\hline 5 Reading & 28 & 90.5 & 8.5 & 74 & 88.2 & 11.7 & 0.94 & .35 & -2.54 & 7.09 \\
\hline 5 Science & 28 & 76.8 & 14.0 & 72 & 75.5 & 16.2 & 0.36 & .72 & -5.65 & 8.15 \\
\hline Attendance & 36 & 96.6 & 0.7 & 97 & 96.4 & 0.5 & 1.30 & .13 & -0.09 & 0.40 \\
\hline \multicolumn{11}{|l|}{$2014-2015$} \\
\hline 3 Reading & 32 & 79.4 & 13.6 & 77 & 80.3 & 11.7 & -0.37 & .71 & -6.08 & 4.18 \\
\hline 4 Reading & 33 & 76.2 & 14.5 & 77 & 78.4 & 13.4 & -0.74 & .46 & -7.78 & 3.54 \\
\hline 4 Writing & 33 & 72.2 & 18.3 & 75 & 72.3 & 14.3 & -0.22 & .98 & -6.54 & 6.40 \\
\hline 5 Reading & 34 & 91.2 & 6.5 & 67 & 86.3 & 12.2 & -2.21 & .03 & -9.43 & -0.43 \\
\hline 5 Science & 30 & 69.4 & 18.9 & 66 & 75.4 & 15.8 & -1.61 & .11 & -13.33 & 1.99 \\
\hline Attendance & 41 & 96.4 & 0.7 & 92 & 96.3 & 0.5 & 1.36 & .17 & -0.07 & 0.38 \\
\hline \multicolumn{11}{|l|}{$2015-2016$} \\
\hline 3 Math & 38 & 77.7 & 14.4 & 75 & 79.8 & 11.9 & -0.81 & .42 & -7.08 & 2.98 \\
\hline 3 Reading & 36 & 74.3 & 14.7 & 75 & 76.6 & 12.4 & -0.83 & .41 & -7.50 & 3.08 \\
\hline 4 Math & 36 & 76.6 & 14.5 & 71 & 77.9 & 12.1 & -0.47 & .64 & -6.48 & 4.01 \\
\hline 4 Reading & 35 & 75.5 & 11.9 & 74 & 77.2 & 12.2 & -0.69 & .49 & -6.63 & 3.19 \\
\hline 4 Writing & 35 & 69.0 & 12.8 & 73 & 71.9 & 13.7 & -1.04 & .30 & -8.33 & 2.61 \\
\hline 5 Math & 34 & 91.0 & 8.6 & 68 & 85.9 & 12.1 & -2.17 & .04 & -9.74 & -0.38 \\
\hline 5 Reading & 34 & 81.3 & 14.1 & 70 & 82.9 & 17.1 & -0.52 & .63 & -7.93 & 5.08 \\
\hline 5 Science & 33 & 72.3 & 17.0 & 65 & 74.8 & 15.0 & -0.70 & .47 & -9.11 & 4.21 \\
\hline
\end{tabular}

2013-2014 school year

As shown in Table 2, a cursory comparison of mean scores reflected several differences, and independent samples $t$-tests were performed to explore the data further and determine statistical significance. Findings revealed one statistically significant finding with STAAR Grade 4 Writing assessment scores, which rejected the null hypothesis for 
STAAR assessment scores $[t(106)=-2.00, p=.05]$. Cohen's $d$ was calculated at .43 , which was considered a small effect.

2014-2015 school year

As shown in Table 2, a cursory comparison of mean scores reflected several differences, and independent samples $t$-tests were performed to explore the data further and determine statistical significance. Findings revealed one statistically significant finding with STAAR Grade 5 Reading assessment scores, which rejected the null hypothesis for STAAR assessment scores $[t(99)=-2.21, p=.03]$. Cohen's $d$ was calculated at .51, which was considered a medium effect.

2015-2016 school year

As shown in Table 2, a cursory comparison of mean scores reflected several differences, and independent samples $t$-tests were performed to explore the data further and determine statistical significance. Findings revealed one statistically significant finding with STAAR Grade 5 Mathematics assessment scores, which rejected the null hypothesis for STAAR assessment scores $[t(50.15)=-2.17, p=.04]$. Cohen's $d$ was calculated at .48, which was considered a small effect.

\section{Level 2 analysis: Students in rural public schools}

This level of data analysis explored the impact of participation in WOWW's fine arts enriched education programming on the academic achievement and attendance among students in rural public schools. Findings from this level of analysis are reported by school year.

2012-2013 school year

As shown in Table 3, a cursory comparison of mean scores reflected several differences, and independent samples $t$-tests were performed to explore the data further and determine statistical significance. Findings revealed the following three statistically significant findings, which rejected the following null hypotheses for STAAR assessment scores and attendance rates:

- STAAR Grade 4 Reading assessment scores: $t(31.95)=3.18, p=.00$. Cohen's $d$ was calculated at .99 , which was considered a large effect.

- STAAR Grade 5 Reading assessment scores: $t(37)=2.28, p=.03$. Cohen's $d$ was calculated at .93, which was considered a large effect.

- Attendance rate: $t(43)=2.51, p=.02$. Cohen's $d$ was calculated at .79 , which was considered a large effect. 
Table 3

All rural schools in Texas's ESC Region 16 Area

\begin{tabular}{|c|c|c|c|c|c|c|c|c|c|c|}
\hline & \multicolumn{3}{|c|}{ WOWW } & \multicolumn{3}{|c|}{ Non-WOWW } & \multirow[b]{2}{*}{$t$} & \multirow[b]{2}{*}{$p$} & \multicolumn{2}{|c|}{$95 \%$ CI } \\
\hline & $n$ & $M$ & $S D$ & $n$ & $M$ & $\bar{S} D$ & & & $\mathrm{LL}$ & UL \\
\hline \multicolumn{11}{|l|}{$2012-2013$} \\
\hline 3 Math & 7 & 69.6 & 17.9 & 22 & 72.3 & 17.5 & -3.54 & .73 & -18.37 & 12.97 \\
\hline 3 Reading & 11 & 86.3 & 17.9 & 27 & 79.7 & 17.0 & 1.06 & .30 & -5.96 & 19.10 \\
\hline 4 Math & 11 & 78.6 & 13.1 & 22 & 73.4 & 20.2 & 0.78 & .44 & -8.49 & 18.95 \\
\hline 4 Reading & 11 & 86.4 & 9.5 & 29 & 72.8 & 17.0 & 3.18 & .00 & 4.88 & 22.26 \\
\hline 4 Writing & 11 & 80.4 & 13.3 & 26 & 71.1 & 18.2 & 1.53 & .14 & -3.07 & 21.64 \\
\hline 5 Math & 10 & 80.2 & 12.4 & 29 & 68.8 & 20.2 & 1.67 & .10 & -2.47 & 25.21 \\
\hline 5 Reading & 10 & 87.4 & 10.6 & 29 & 73.5 & 18.2 & 2.28 & .03 & 1.52 & 26.31 \\
\hline 5 Science & 10 & 77.1 & 12.7 & 25 & 74.3 & 17.9 & 0.45 & .65 & -9.84 & 15.48 \\
\hline Attendance & 12 & 96.9 & 1.0 & 33 & 96.3 & 0.7 & 2.51 & .02 & 0.12 & 1.11 \\
\hline \multicolumn{11}{|l|}{$2013-2014$} \\
\hline 3 Math & 13 & 76.5 & 16.0 & 23 & 69.9 & 16.9 & 1.15 & .26 & -5.10 & 18.28 \\
\hline 3 Reading & 14 & 83.0 & 14.7 & 26 & 83.7 & 10.6 & -0.17 & .87 & -10.00 & 8.48 \\
\hline 4 Math & 12 & 73.8 & 12.9 & 24 & 70.6 & 22.2 & 0.54 & .59 & -8.77 & 15.10 \\
\hline 4 Reading & 11 & 80.9 & 14.3 & 25 & 75.9 & 15.0 & 0.93 & .35 & -5.87 & 15.85 \\
\hline 4 Writing & 11 & 73.0 & 16.6 & 23 & 74.4 & 15.6 & -0.24 & .81 & -13.26 & 10.48 \\
\hline 5 Math & 11 & 93.4 & 7.0 & 26 & 86.3 & 14.5 & 2.01 & .05 & -0.09 & 14.28 \\
\hline 5 Reading & 10 & 93.8 & 8.7 & 27 & 86.9 & 15.1 & 1.36 & .18 & -3.41 & 17.24 \\
\hline 5 Science & 10 & 83.1 & 8.8 & 25 & 72.5 & 14.9 & 2.09 & .05 & 0.28 & 20.88 \\
\hline Attendance & 15 & 96.8 & 0.9 & 29 & 96.4 & 0.7 & 1.51 & .13 & -0.13 & 0.88 \\
\hline \multicolumn{11}{|l|}{$2014-2015$} \\
\hline 3 Reading & 15 & 84.9 & 11.3 & 21 & 81.1 & 11.6 & 0.99 & .33 & -4.05 & 11.69 \\
\hline 4 Reading & 16 & 81.7 & 13.3 & 21 & 83.9 & 13.7 & -0.49 & .63 & -11.26 & 6.92 \\
\hline 4 Writing & 16 & 80.3 & 16.3 & 19 & 73.3 & 15.7 & 1.28 & .20 & -4.09 & 17.96 \\
\hline 5 Reading & 18 & 87.4 & 14.6 & 19 & 91.8 & 7.0 & -1.16 & .26 & -12.23 & 3.44 \\
\hline 5 Science & 14 & 70.1 & 22.1 & 18 & 72.2 & 21.0 & -0.27 & .79 & -17.64 & 13.59 \\
\hline Attendance & 21 & 96.6 & 0.7 & 24 & 96.3 & 0.7 & 1.71 & .09 & -0.06 & 0.73 \\
\hline \multicolumn{11}{|l|}{$2015-2016$} \\
\hline 3 Math & 21 & 78.4 & 16.3 & 19 & 75.6 & 13.6 & 0.58 & .57 & -6.92 & 12.42 \\
\hline 3 Reading & 19 & 78.8 & 15.7 & 19 & 75.7 & 14.3 & 0.63 & .54 & -6.84 & 12.95 \\
\hline 4 Math & 19 & 79.6 & 13.8 & 15 & 74.2 & 14.7 & 1.11 & .28 & -4.55 & 15.42 \\
\hline 4 Reading & 18 & 76.0 & 13.5 & 18 & 75.1 & 15.0 & 0.18 & .86 & -8.82 & 10.49 \\
\hline 4 Writing & 18 & 69.7 & 13.0 & 17 & 74.1 & 16.9 & -0.88 & .39 & -14.77 & 5.87 \\
\hline 5 Math & 18 & 85.4 & 14.1 & 20 & 88.0 & 12.0 & -0.59 & .56 & -11.09 & 6.07 \\
\hline 5 Reading & 18 & 82.3 & 16.5 & 20 & 88.5 & 10.8 & -1.38 & .18 & -15.24 & 2.90 \\
\hline 5 Science & 17 & 71.7 & 21.4 & 17 & 70.7 & 21.0 & 0.14 & .89 & -13.81 & 15.81 \\
\hline
\end{tabular}

2013-2014 school year

As shown in Table 3, a cursory comparison of mean scores reflected several differences, and independent samples $t$-tests were performed to explore the data further and determine statistical significance. Findings revealed two statistically significant findings, which rejected the following null hypotheses for STAAR assessment scores: 
- STAAR Grade 5 Math assessment scores: $t(34.22)=2.01, p=.04$. Cohen's $d$ was calculated at 60 , which was considered a medium effect.

- STAAR Grade 5 Science assessment scores: $t(33)=2.09, p=.05$. Cohen's $d$ was calculated at .86 , which was considered a large effect.

2014-2015 school year

As shown in Table 3, a cursory comparison of mean scores reflected several differences, and independent samples $t$-tests were performed to explore the data further and determine statistical significance. Findings showed that no statistical significance was present with mean differences between Group 1 and Group 2 for STAAR assessment scores or attendance rates among students in rural public schools.

2015-2016 school year

As shown in Table 3, a cursory comparison of mean scores reflected several differences, and independent samples $t$-tests were performed to explore the data further and determine statistical significance. Findings showed that no statistical significance was present with mean differences between Group 1 and Group 2 for STAAR assessment scores or attendance rates among students in rural public schools.

\section{DISCUSSION AND IMPLICATIONS}

The purpose of the current study was to explore the impact of participation in WOWW's fine arts and enriched education programming among public schools located in Texas's ESC Region 16 area. To achieve this purpose, campus attendance rates and STAAR Level II performance standards for required assessments administered in Grades 3, 4, and 5 were explored using two levels of data analyses. Level 1 data analyses explored mean differences between students who participated in WOWW programming (Group 1) and those who did not (Group 2) among all public schools located in Texas's ESC Region 16 area. In an effort to drill deeper into the data, Level 2 data analyses explored mean differences between the two groups among public schools located in school districts categorized as rural.

Findings from the current study presented empirical evidence that have pointed to possible benefits associated with participation in WOWW's fine arts enriched education programming. With respect to the Level 1 analyses, findings revealed four statistically significant relationships between participation in WOWW's fine arts enriched education programming and attendance rates, as well as student academic performance in mathematics, reading, science, and writing. Similarly, findings from Level 2 analyses revealed five statistically significant relationships between participation in WOWW's fine arts enriched education programming and attendance rates, as well as student academic performance in reading, mathematics, and science. Although these relationships did not reflect a predictable pattern throughout each school year, the findings of the current study add to existing literature for learning through the arts and point to implications for public school educators at the elementary grade levels. 
Students who engage in learning activities enriched with the fine arts have the potential to experience a myriad of benefits, including the development of instrumental $21^{\text {st }}$ century skills - critical thinking, problem solving, communication, and collaboration (Arts Education Partnership, 2016). Additionally, learning through the fine arts has been linked to enhanced cognitive processes (Bolwerk et al., 2014; Demarin et al., 2016; Dunbar, 2008; Posner et al., 2008; Solso, 1994); and improved academic performance (Anderson, 2012; Anderson \& Loughlin, 2014; Ingram \& Riedel, 2003; Peppler et al., 2014) and retention of academic content (Hardiman et al., 2014; Rinne et al., 2011). Thus, all classroom teachers at the elementary grade levels should seek ways to integrate the arts throughout their content curriculum (i.e., mathematics, reading, science, and writing) consistently and frequently. Unfortunately, classroom teachers receive very little preparation with the arts during their teacher training, which often leads to low levels of self-efficacy towards integrating the arts effectively (Battersby \& Cave, 2014; Oreck, 2004). Therefore, classroom teachers must actively seek professional learning activities with which to strengthen their pedagogical understandings and professional knowledge of the arts (Russell-Bowie, 2011). These professional learning activities should be coordinated and led by arts specialists who are employed within the school district, surrounding school districts, or adjacent institutions of higher learning.

Classroom teachers and school administrators should also seek ways to expose students to fine arts enriched learning experiences taught by qualified arts specialists. However, many public schools, especially rural schools, have extremely limited resources for such experiences (Clark \& Zimmerman, 2000; Heinrich, 2012; Seidel, 2013). Under these circumstances, schools should establish partnerships with external community arts-based organizations, such as art galleries, museums, or performing arts center (Arts Education Partnership, 1999). Sustainable partnerships require both partners - the public school and the community-based arts organization - to have a shared vision and articulate goals that ultimately promote and improve student learning. Partnerships with community arts-based organizations have the potential to enrich how learning through the arts is addressed within schools (Vitulli, Santoli, \& Fresne, 2013) and generally produce the most positive benefits among students after three to five years (Brezovnik, 2015).

\section{LIMITATIONS}

Although each level of analyses presented interesting findings, it is important to note a few limitations associated with the current study, along with recommendations for future studies. First, the current study was limited to public schools located within Texas's ESC Region 16 area. At the time, WOWW was the only provider of its kind in the ESC Region 16 area and one of two known providers in Texas. Therefore, we recommend that future studies replicate our methodology and continue to explore the impact of WOWW's fine arts enriched education programming on the attendance rates and student academic performance in mathematics, reading, science, and writing among public schools located in Texas's ESC Region 16 area to either confirm or dispute the current findings. 
Another limitation was related to the comparability of the two groups. Unlike experimental research designs, it was not possible to use random grouping in the design of the current study. Thus, this inability to employ random grouping posed potential threats to internal validity. In the current study, the control group for each school year included in data analyses was comprised of school campuses that were not WOWW partner schools and served students at the elementary grade levels. We intentionally selected this grouping technique because more than half of the public school districts located in Texas's ESC Region 16 area were categorized as rural. However, in order to address potential threats to internal validity, we suggest that researchers consider using TEA's campus comparison group data sets for future studies.

\section{REFERENCES}

Adams, J. H. (2016). Dance and literacy hand in hand: Uncommon practices to meet the Common Core. Journal of Dance Education, 16(1), 31-34. doi:10.1080/15290824.2015.1059941

An, S., Capraro, M. M., \& Tillman, D. A. (2013). Elementary teachers integrate music activities into regular mathematics lessons: Effects on students' mathematical abilities. Journal for Learning through the Arts, 9(1), 1-19. Retrieved from http://escholarship.org/uc/class_lta

Anderson, A. (2012). The influence of process drama on elementary students' written language. Urban Education, 47(5), 959-982. doi:10.1177/0042085912446165

Anderson, A., \& Loughlin, S. M. (2014) The influence of classroom drama on English learners' academic language use during English language arts lessons. Bilingual Research Journal, 37(3), 263-286. doi:10.1080/15235882.2014.965360

Arts Education Partnership. (1999). Learning partnerships: Improving learning in schools with arts partners in the community. Retrieved from http://www.aeparts.org/wp-content/uploads/Learning-Partnerships.pdf

Arts Education Partnership. (2016). Mission/overview. Retrieved from http://www.aeparts.org/about-aep/missionoverview/

Battersby, S. L., \& Cave, A. (2014). Preservice classroom teachers' preconceived attitudes, confidence, beliefs, and self-efficacy toward integrating music in the elementary curriculum. Update: Applications of Research in Music Education, 32(2), 52-59. doi:10.1177/8755123314521033

Block, B. A. (2001). Literacy through movement: An organizational approach. Journal of Physical Education, Recreation \& Dance, 72(1), 39-48. doi:10.1080/07303084.2001.10605819

Bolwerk, A., Mack-Anderson, J., Lang, F. R., Dörfler, A., \& Maihöfner, C. (2014). How art changes your brain: Differential effects of visual art production and cognitive art evaluation on functional brain connectivity. PLOS ONE, 9(7), 1-8. doi:10.1371/journal.pone.0101035 
Brezovnik, A. (2015). The benefits of fine art integration into mathematics in primary school. Center for Educational Policy Studies Journal, 5(3), 11-32. Retrieved from http://www.cepsj.si/doku.php?id=en:cepsj

Bush, S. B., Karp, K. S., Lentz, T., \& Nadler, J. (2017). When Venn diagrams intersect art \& math. Teaching Children Mathematics, 23(7), 414-421. doi:10.5951/teacchilmath.23.7.0414

Campbell, S. (2001). Shous in the dark: Community arts organizations for students in rural schools with "urban" problems. Education and Urban Society, 33(4), 445-456. doi: $10.1177 / 0013124501334007$

Carrier, S., Wiebe, E. N., Gray, P., \& Teachout, D. (2011). BioMusic in the classroom: Interdisciplinary elementary science and music curriculum development. School Science and Mathematics, 111(8), 425-434. doi:10.1111/j.1949-8594.2011.00116.x

Christianakis, M. (2011). Hybrid texts: Fifth graders, rap music, and writing. Urban Education, 46(5), 1131-1168. doi:10.1177/0042085911400326

Clark, G., \& Zimmerman, E. (2000). Greater understanding of the local community: A community-based art education program for rural schools. Art Education, 53(2), 33-39. doi: $10.2307 / 3193848$

Cohen, J. (1992). A power primer. Psychological Bulletin, 112(1), 155-159. doi:10.1037/0033-2909.112.1.155

Crowther, G. J., Mcfadden, T., Fleming, J. S., \& Davis, K. (2016). Leveraging the power of music to improve science education. International Journal of Science Education, 38(1), 73-95. doi:10.1080/09500693.2015.1126001

Dambekalns, L., \& Medina-Jerez, W. (2012). Cell organelles and silk batik: A model for integrating art and science. Science Scope, 36(2), 44-51. Retrieved from http://www.nsta.org/middleschool/

Demarin, V., Bedeković, M. R., Puretić, M. B., \& Pašić, M. B. (2016). Arts, brain and cognition. Psychiatria Danubina, 28(4), 343-348. Retrieved from http://www.hdbp.org/psychiatria_danubina/index.html

Dunbar, K. N. (2008). Arts and cognition mongraph: Art education, the brain, and language. Retrieved from The Dana Foundation website: http://www.dana.org/Publications/ReportDetails.aspx?id=44249

Education Service Center Region 16. (n.d.). About Region 16 Education Service Center. Retrieved from http://www.esc16.net/default.aspx?name=about.home

Fleming, M., Merrell, C., \& Tymms, P. (2004). The impact of drama on pupils' language, mathematics, and attitude in two primary Sschools. Research in Drama Education: The Journal of Applied Theater and Performance, 9(2), 177-197. doi:10.1080/1356978042000255067 
Frambaugh-Kritzer, C., Buelow, S., \& Steele, J. S. (2015). What are disciplinary literacies in dance and drama in the elementary grades? Journal of Language and Literacy Education, 11(1), 65-87. Retrieved from http://jolle.coe.uga.edu/

Frasher, K. D. (2014). Music and literacy: Strategies using Comprehension Connections by Tanny McGregor. General Music Today, 27(3), 6-9. doi:10.1177/1048371314520968

Garcia, C., Jones, D. \& Isaacson, C. (2015). Comparing state mandated test scores for students in programs with and without fine arts in the curriculum. Journal of Case Studies in Education, 7, 1-20. Retrieved from http://www.aabri.com/jcse.html

Greenfader, C. M., \& Brouillette, L. (2013). Boosting language skills of English learners through dramatization and movement. The Reading Teacher, 67(3), 171-180. doi:10.1002/TRTR.1192

Hall, S. N., \& Robinson, N. R. (2012). Music and reading: Finding connections from within. General Music Today, 26(1), 11-18. doi:10.1177/1048371311432005

Hansen, D., \& Bernstorf, E. (2002). Linking music learning to reading instruction. Music Educators Journal, 88(5), 17-21. doi:10.2307/3399821

Hardiman, M., Rinne, L., \& Yarmolinskaya, J. (2014). The effects of arts integration on long-term retention of academic content. Mind, Brain \& Education, 8(3), 144-148. doi: $10.1111 / \mathrm{mbe} .12053$

Heinrich, J. (2012). The provision of classroom music programs to regional Victorian primary schools. Australian Journal of Music Education, 2, 45-58. Retrieved from http://www.asme.edu.au/publications/

Helsa, Y., \& Hartono Y. (2011). Designing reflection and symmetry learning by using math traditional dance in primary school. Journal on Mathematics Education, 2(1), 7994. Retrieved from http://ejournal.unsri.ac.id/index.php/jme/index

Ingram, D., \& Riedel, E., (2003). Arts for academic achievement: What does arts integration do for students? Retrieved from http://www.cehd.umn.edu/carei/publications/documents/DoforStudents.pdf

Jones, S. M., \& Pearson, D., Jr. (2013). Music: Highly engaged students connect music to math. General Music Today, 27(1), 18-23. doi:10.1177/1048371313486478

Kerby, H. W., Cantor, J., Weiland, M., Babiarz, C., \& Kerby, A. W. (2010). Fusion Science Theater presents The Amazing Chemical Circus: A new model of outreach that uses theater to engage children in learning. Journal of Chemical Education, 87(10), 1024-1030. doi:10.1021/ed100143j

LaBrocca, R., \& Morrow, L. (2016). Embedding vocabulary instruction into the art experience. The Reading Teacher, 70(2), 149-158. doi:10.1002/trtr.1488 
LaGarry, A. E., \& Richard, B. (2016). Arts integration in rural Minnesota: A collaborative arts integration framework. Arts Education Policy Review, 1-12. doi:10.1080/10632913.2016.1236306

Lee, B. K., \& Enciso, P. (2017). The Big Glamorous Monster (or Lady Gaga's Adventures at Sea): Improving student writing through dramatic approaches in schools. Journal of Literacy Research, 49(2), 157-180. doi:10.1177/1086296X17699856

Leigh, S. R. (2012). Writers draw visual hooks: Children's inquiry into writing. Language Arts, 89(6), 396-404. Retrieved from http://www.ncte.org/journals/la/

Luftig, R. L. (2000). An investigation of an arts infusion program on creative thinking, academic achievement, affective functioning, and arts appreciation of children at three grade levels. Studies in Art Education, 41(3). 208-227. doi:10.2307/1320378

Lund Research Ltd. (2013). Independent t-test using SPSS Statistics. Retrieved from https://statistics.laerd.com/spss-tutorials/independent-t-test-using-spss-statistics.php

McPherson, S. (2009). A Dance with the Butterflies: A metamorphosis of teaching and learning through technology. Early Childhood Education Journal, 37(3), 229-236. doi:10.1007/s10643-009-0338-8

Oreck, B. (2004). The artistic and professional development of teachers. Journal of Teacher Education, 55(1), 55-69. doi:10.1177/0022487103260072

Parsad, B., \& Spiegelman, M. (2012). Arts education in public elementary and secondary schools: 1999-2000 and 2009-10 (NCES 2012-014). National Center for Education Statistics, Institute of Education Sciences, U.S. Department of Education. Washington, D.C.. Retrieved from http://nces.ed.gov/pubs2012/2012014.pdf

Peppler, K. A., Powell, C. W., Thompson, N., \& Catterall, J. (2014). Positive impact of arts integration on student academic achievement in English language arts. The Educational Forum, 78(4), 364-377. doi:10.1080/00131725.2014.941124

Plankis, B., Ramsey, J., Ociepka, A., \& Martin, P. (2016). The Lorax readers' theater: Introducing sustainability with an integrated science and literacy activity. Science and Children, 53(7), 34-40. Retrieved from http://www.nsta.org/elementaryschool/

Poldberg, M., Trainin, G., \& Andrzejczak, N. (2013). Rocking your writing program: Integration of visual art, language arts, \& science. Journal for Learning through the Arts, 9(1), 1-20. Retrieved from http://escholarship.org/uc/class_lta

Porter, K., Yokoi, C., \& Yee, B. (2011). The art and science of notebooks: An interdisciplinary approach to teaching students to record accurately. Science and Children, 49(2), 42-46. Retrieved from http://www.nsta.org/elementaryschool/

Posner, M., Rothbart, M. K., Sheese, B. E., \& Kieras, J. (2008). How arts training influeces cognition. In C. Asbury \& B. Rich (Eds.), Learning, arts, and the brain: The Dana Consortium report on arts and cognition (pp. 1-10). New York, NY: Dana Press. 
Raymond, A., \& Broderick, P. (2007). Teaching and learning with the arts. Teaching Pre K-8, 37(6), 36-39. Retrieved from http://www.magazine-agent.com/Teaching-PreK-8/Magazine

Rinne, L., Gregory, E., Yarmolinskaya, J., \& Hardiman, M. (2011). Why arts integration improves long-term retention of content. Mind, Brain, and Education, 5(2), 89-96. doi:10.1111/j.1751-228X.2011.01114.X

Rosenfeld, M. (2011). Jump patterns: Percussive dance and the path to math. Teaching Artist Journal, 9(2), 78-89. doi:10.1080/15411796.2011.556564

Russell-Bowie, D. (2011). An ode to joy ... or the sounds of silence? An exploration of arts education policy in Australian primary schools. Arts Education Policy Review, 112(4), 163-173. doi:10.1080/10632913.2011.566099

Seidel, S. (2013). Exploding parameters and an expanded embrace: A proposal for the arts in education in the twenty-first century. Harvard Educational Review, 83(1), 1-4. doi:10.17763/haer.83.1.q8q24t6859494833

Shaw, D. G., \& Nygard, B. (1997). Moving through the solar system: Using movement activities to learn about the solar system. Science Activities: Classroom Projects and Curriculum Ideas, 34(3), 23-31. doi:10.1080/00368129709602977

Snyder, K. M., \& Cooper, K. (2015). Innovating schools through dialogic arts-based practice: Ingredients for engaging students with a whole new mind. Journal for Learning through the Arts, 11(1), 1-20. Retrieved from http://escholarship.org/uc/class_lta

Solso, R. L. (1994). Cognition and the visual arts. Cambridge, MA: The MIT Press.

Sutil, N. S.. (2014). Performance/mathematics: A dramatisation of mathematical methods. International Journal of Performance Arts and Digital Media, 10(2), 143-158. doi:10.1080/14794713.2014.946283

Texas Education Agency. (2017a). Curriculum standards. Retrieved from http://tea.texas.gov/Curriculum_and_Instructional_Programs/Curriculum/

Texas Education Agency. (2017b). District type data search. Retrieved from http://tea.texas.gov/acctres/analyze/years.html

Texas Education Agency. (2017c). District type glossary of terms, 2014-15. Retrieved from http://tea.texas.gov/acctres/analyze/1415/gloss1415.html\#Rural

Texas Education Agency. (2017d). Texas Academic Performance Report. Retrieved from https://rptsvr1.tea.texas.gov/perfreport/tapr/

Texas System of Education Service Centers. (n.d.). History of ESCs. Retrieved from http://www.texasresc.net/about-escs/

Van Buren, B. (1986). Improving reading skills through elementary art experiences. Art Education, 39(1), 56-61. doi:10.2307/3192943 
Vitulli, P., Santoli, S. P., \& Fresne, J. (2013). Arts in education: Professional development integrating the arts and collaborating with schools and community. International Journal of Pedagogies \& Learning, 8(1), 45-52. doi: 10.5172/ijpl.2013.8.1.45

Wiles, P. J. (2004). Plan for education program. Amarillo, TX: Globe-News Center for the Performing Arts.

Young, C., Valadez, C., \& Gandara, C. (2016). Using performance methods to enhance students' reading fluency. The Journal of Educational Research, 109(6), 624-630. doi:10.1080/00220671.2015.1016599 